\title{
E-Portal For Construction Engineering Managers: FRAMEWORK AND 4-TIER ARCHTECTURE
}

\author{
Boong-yeol Ryoo and Mirosław J. Skibniewski
}

\author{
Division of Construction Engineering and Management, School of Civil Engineering \\ Purdue University \\ West Lafayette, IN 47907-1294, USA \\ bryoo@purdue.edu; mirek@purdue.edu
}

\begin{abstract}
Electronic construction information portals have become popular in recent years but most portals are intended for business transaction processing. This paper describes a web-based construction information portal (e-Portal) intended for use by construction engineers. A functional framework for the portal is presented along with a 4-Tier architecture including the Presentation Layer, Application Layer, Application Programming Interface(API) Layer, and the Database Layer. Construction related information such as legal regulations, standard specifications, technical manuals, construction materials and manufacturers is organized and presented to reflect the multiple functions of the e-Portal. With the presented e-Portal architecture, construction information can be acquired and processed via a Wireless Application Protocol (WAP), mobile devices, and WWW(World Wide Web) with the use of the Extensible Mark-up Language (XML) and Extensible Stylesheet Language (XSL)).
\end{abstract}

KEYWORDS: e-Commerce, e-Portal, 4-Tier architecture, Construction Engineering and Management

\section{INTRODUCTION}

IT (Information technology) infrastructure including network and hardware is now wellestablished in developed nations. Implementation practices in business industry are remarkable but not evolving rapidly at this time due to the slow global economy at the start of the $21^{\text {st }}$ century. Electronic portal business in the construction industry has also suffered to some extent, but consortia of major construction companies have developed electronic business portals as a market place for construction materials. These portals focus mainly on buying and selling materials. In other developments, some governments around the world require electronic submission of construction related documentation for contractors involved in public projects.

Electronic networking technologies already have an established place in the engineering and business worlds, including the construction industry (Abduh and Skibniewski 2002a; 2002b). However, it is important to consider the limitations of the professional environment before a successful launch of an IT based solution can be realized (Abduh and Skibniewski 2003).
Focusing on South Korea as an example, construction information related to public projects such as drawings, specifications, and budgets must be submitted electronically to the government (MOCT 2001). However, access of electronic sources of construction information, e.g. construction laws and regulations, standard specifications and manuals, construction materials and manufacturers' data, national performance standards, etc. is limited.

Public construction project information is part of the public domain but it has not been fully organized and made available electronically to the public. Construction engineering and management require a variety of sources of information and knowledge due to the fragmentation of construction project participants. Most publicly owned corporations in Korea have developed construction management information systems based on Computer-Aided Acquisition and Logistics Support/ Contractor Integrated Technical Information Service (CALS/CITIS) standards and the CALS Implementation plan developed in 1997. Construction management information systems are intranet systems and are only open to project participants. Thus, neither quantitative 
nor qualitative information is exchangeable electronically among construction engineers in the public domain.

Career management of engineers in construction in Korea is mandatory. The Korea Construction Engineers Association (KOCEA), a public corporation founded in 1987, is currently responsible for career record management and the training of engineers in construction industry. Career management is an obligatory affair by law but training is voluntary. The primary objective of KOCEA is to supervise and manage business and services in the area of career management. There are over 1.6 million engineers and about 36,000 contractors and sub-contractors working in the Korean construction industry. Submitting official records of each engineer to project owners, including personal records of education and training and project related experience, is mandatory.

Due to the downsizing of the Korean government budget, KOCEA is now considering changes in the existing business models and pursuing profits goals from new business ventures. Eventually, the Korean government plans to transfer the management of engineering records to KOCEA. Thus, the development of new business models is imminent. Electronic portal business is considered as a new business model because a significant number of construction companies and engineers have close relationships with KOCEA.

\section{ELECTRONIC ACCESS TO CONSTRUCTION INFORMATION}

There is no single gateway providing access to construction information available over the Internet. Various types of electronic business portals such as e-market place, e-procurement, and e-distribution focus on business transactions related to construction materials, suppliers and manufacturers (Ryoo 2001). Project specific portals utilized by diverse project teams operate typically within an Intranet, and are off-limits to individuals and businesses not directly associated with the given project. In order to provide relevant information to engineers in the public domain, open access to construction industry information is necessary.

Contractors are now being asked by public project owners to submit all construction project documents in a pre-defined digital format so that they are accessible over the Internet by the public (MOCT 2001). Using those electronic business portals is troublesome since the information does not meet the national formatting standards. Existing information systems do not allow internet users to access intranet information systems. A web-based e-Portal can be a unique source of construction project and industry information.

A functional framework and system architecture for a construction information portal is the subject of this paper. The information portal requires a significant amount of information uploads and execution of construction programs. Current three-tier systems are designed for business management systems within similar platforms. Four-tier architecture is proposed in order to reduce the limitations in integrating construction programs and various external databases.

\section{OBJECTIVES AND SCOPE}

The primary task includes the development of a functional map of an e-Portal suitable for the construction industry. e-Community and eProjects have been implemented in Phase 1 of the portal development.

Functionally, an e-Portal must meet the national CALS/CITIS standards. Thus, the following tasks are also required:

- Set up a portal compatible with existing Intranet and Internet systems

- Integrate existing web sites and their databases

- Set up a special module for the Asia Pacific Economic Cooperation (APEC) Engineers and independent contractors

In order to be able to support the engineers and contractors, the following additional considerations are included:

- A unified gateway to web sites in construction

- Allowing private and virtual workspace for contractors and engineers

- Offering continuing professional training courses over the Internet

- Offering Application Service Provider (ASP) and consultation services to contractors

- Providing information on construction industry and project information compatible with Intranets 
- Considering commercial services for construction engineers in the future

Finally, the following technical aspects are also considered:

- Developing a platform-independent architecture

- Keep low maintenance costs and easy operability

- Providing function expandability and scalability

\section{METHODLOGY AND APPROACH}

Functional framework and system architecture comprise six modules: "e-Community" module containing construction policy and economy, "eProjects" containing engineering and construction project information, "e-Campus" opening virtual training opportunity, "e-Consultation" for arranging consultation among engineers and firms, "e-Engineers" for career management of enrolled domestic and overseas engineers, and "e-Mall" to create a cyber market place in the future.

Web development technology proposed by Dmind (2001) has been adopted. Dmind presented an eXtensible Mark-up Language (XML)-based platform for contents management. Four-tier architecture is considered due to various applications and legacy systems that are widely used in construction. The four tiers are "Presentation Layer" as user interface, "Application Layer" as contents manager, "Application Programming Interface (API) Layer" as a bridge between programs, and "Database Layer" as adapter to access databases. Unlike in a three-tier architecture, the Application Layer splits into two layers: Application Layer proper and API Layer. The API Layer is responsible for accessing the applications and legacy systems including their databases. Thus, integration of new systems and legacy systems is accomplished.

\section{CAREER MANAGEMENT PRACTICE IN KOREA}

Engineers' career records include two types of career information: occupation and professional information. Each engineer is responsible for providing and updating his or her career information to KOCEA. Professional information includes fourteen major specialty fields, fifty-three professional divisions, thirty-one types of construction projects, and thirty-one types of job assignments. In addition, project specific information such as construction methods and specific position/title of the engineer is included.

Table 1 shows the classification index to categorize and classify engineers based on the factors listed above.

Table 1. Classification Index of Engineers(KOCEA 2001; 2003)

\begin{tabular}{|l|l|l|l|}
\hline Fields of Construction & \multicolumn{1}{|c|}{$\begin{array}{c}\text { Certificates and } \\
\text { Licenses }\end{array}$} & \multicolumn{1}{|c|}{ Level of Expertise } & \multicolumn{1}{|c|}{ Education } \\
\hline Civil & Professional Engineer & Expert & Ph.D. \\
Architecture & Engineer & Advanced & Master \\
Mechanical & Associate Engineer & Intermediate & Bachelor \\
Regional Planning \& & Technician & Beginner & Associate-Bachelor \\
Development & & & Diploma \\
Safety Management & & & \\
Transportation & & & \\
Environmental & & & \\
Electrical & & \\
Metallurgical & & & \\
Electronic & & \\
Mining \& Resources & & & \\
Industrial Applications & & & \\
Chemical \& Ceramic & & & \\
Textiles & & & \\
\hline
\end{tabular}

The career management information process has been defined by KOCEA as shown in Figure 1 . 
The engineers are grouped and classified based on the construction specialty, possession of certificates or licenses, and levels of expertise and education. Over 480,000 of about 1.6 million engineers in Korea are listed. Table 2 shows the distribution of engineers in major construction fields.

Information

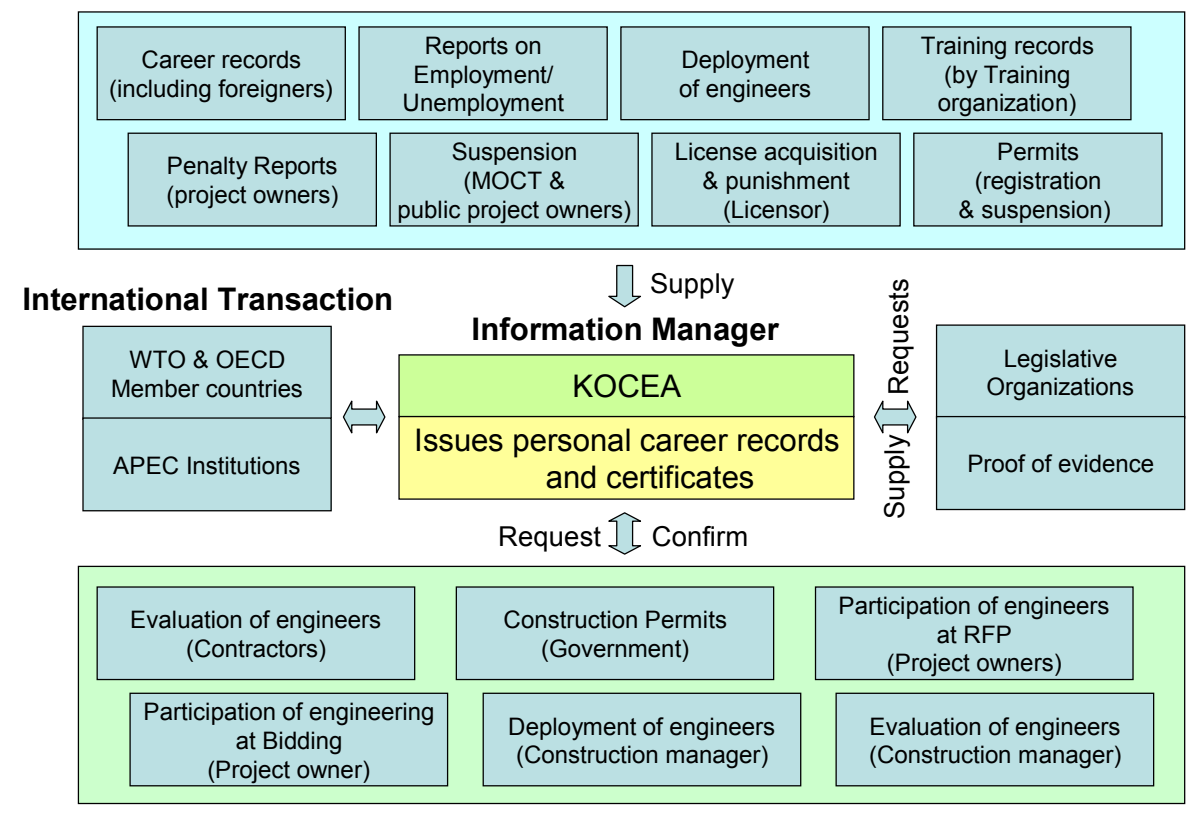

Information Users

Figure 1. Business Process of Career management by KOCEA (KOCEA 2002)

About eight percent of the engineers listed are categorized as civil, architecture (residential and building), mechanical, regional planning and development, and safety management. Forty-one percent of the enlisted engineers do not have a certificate or license. Twenty-five percent of the engineers are beginner level. Forty-eight percent hold at least associate-bachelor degree or above.

Table 2. Construction Engineers managed by KOCEA as of December 2003.

\begin{tabular}{|l|c|l|c|}
\hline Fields of Construction & No. of Engineers & Fields of Construction & No. of Engineers \\
\hline Civil & 153,784 & Metallurgical & 1,803 \\
\hline Architecture & 155,197 & Electronic & 3,623 \\
\hline Mechanical & 50,791 & Mining \& Resources & 2,017 \\
\hline $\begin{array}{l}\text { Regional Planning \& } \\
\text { Development }\end{array}$ & 22,429 & Industry Application & 320 \\
\hline Safety Management & 16,962 & Chemical \& Ceramic & 779 \\
\hline Transportation & 798 & Textiles & 45 \\
\hline Environmental & 8,706 & Miscellaneous & 59,888 \\
\hline Electrical & 6,040 & \multicolumn{1}{|c|}{ Total } & 483,182 \\
\hline
\end{tabular}

A survey was performed to investigate the use of information technology in the construction industry. Design and construction organizations in five major cities including Seoul, Busan, Daegu, Kwangju, and Daejeon have participated in the survey. Engineers in the fields of architectural engineering, construction, construction management and construction supervision in civil and building construction are included. The surveys focused on the familiarity 
with information technology of the construction engineers at main offices and project sites. The following are the key factors.

- The exposure of construction engineers to information technology

- The degree of computerization of the workplace

- The accessibility of network, hardware and software environment

- The preference of construction contents

- The serviceability of existing construction portals

The survey also shows that $38 \%$ of engineers use the internet less than one hour daily and $29 \%$ of them use from two to three hours daily. $87 \%$ are able to use Asymmetric Digital Subscriber Line (ADSL) or Wide Area Network (WAN). 46\% use the Internet because of easy access to it and up-todate construction-related information available. Commercial portals are frequently used to find and download construction information by $49 \%$ of the engineers. E-mailing is second in use at $22 \%$. Figure 2 shows the types of construction information requested by construction engineers. They are concerned with law and regulations, specifications and design guidelines, new technology, project bid announcements, construction materials and prices. It follows that a successful e-Portal should include general construction information on engineering and construction and project bids.

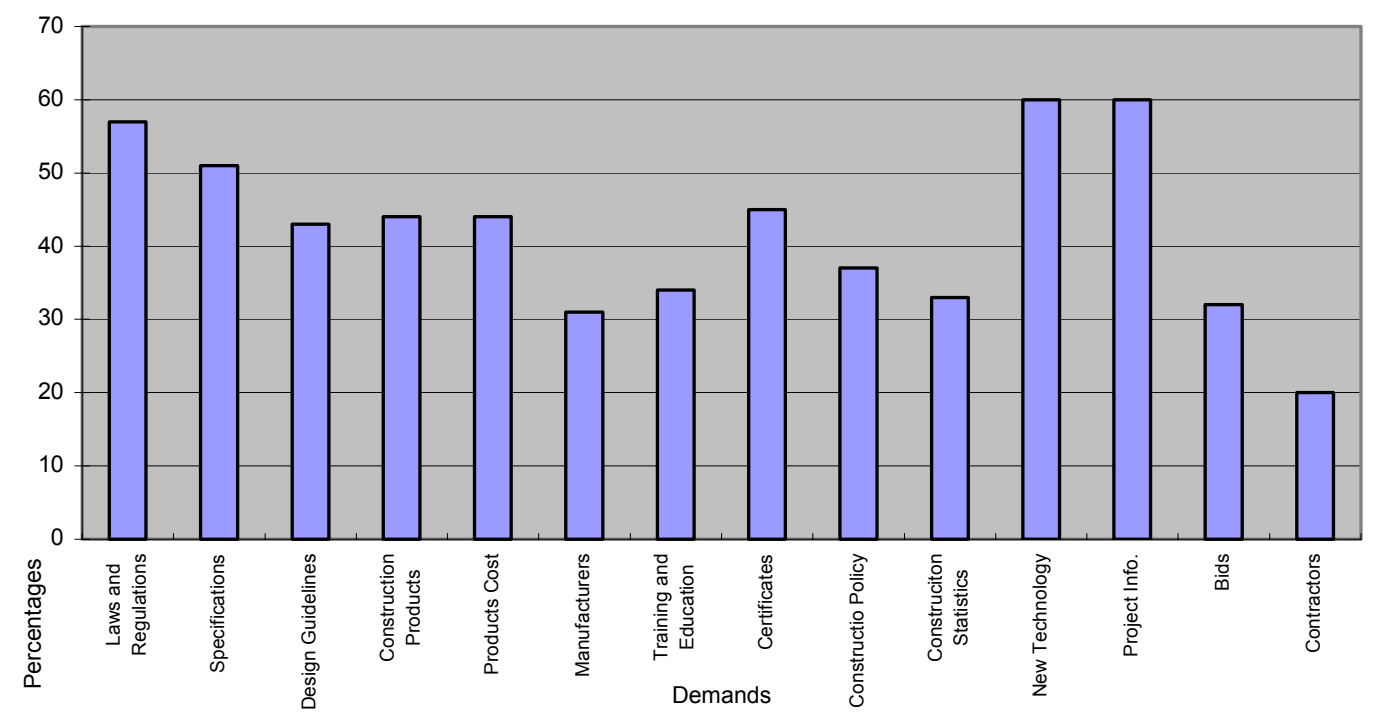

Figure 2. Demand for Construction Information.

\section{1 e-Business Portals in Construction}

Prior to 1990 's, quality was not a major concern due to development-oriented policy in the construction industry in Korea. After a series of engineering and construction failures, the government established strict regulations to improve quality, enforce safety regulations, and increase productivity of engineering and construction. As a result, KOCEA manages and certifies official career records of about $25 \%$ of construction engineers. Submitting certified career records becomes mandatory. Moreover, the domestic construction market is open to international constructors according to the agreements with the World Trade Organization (WTO) and APEC put into effect in January 1997.
There are four organizations such as the Korea Institute of Architects, Korea Professional Engineers Association, Korea Civil Engineers Association, and Korea Surveyors Association, to manage professional careers of their constituents in Korea. There is currently no unified approach to data formats and contents.

\section{FUNCTIONAL FRAMEWORK AND ARCHITECTURE}

The six modules of the e-Portal are shown in Figures 3 and 4. The e-Portal serves as a principal gateway to other construction portals and becomes a knowledge management system for construction professionals. Figure 5 shows the sub-functions of e-Portal developed based on the conducted 
surveys and subsequent business process reengineering.

Contents such as business process and rules, software components, data sources, and legacy applications can be managed, in addition to traditional content such as images, static HTML, documents, etc. since the definition of contents becomes wider (Dmind 2001). However, additional utility functions are needed to support the transactions of contents.

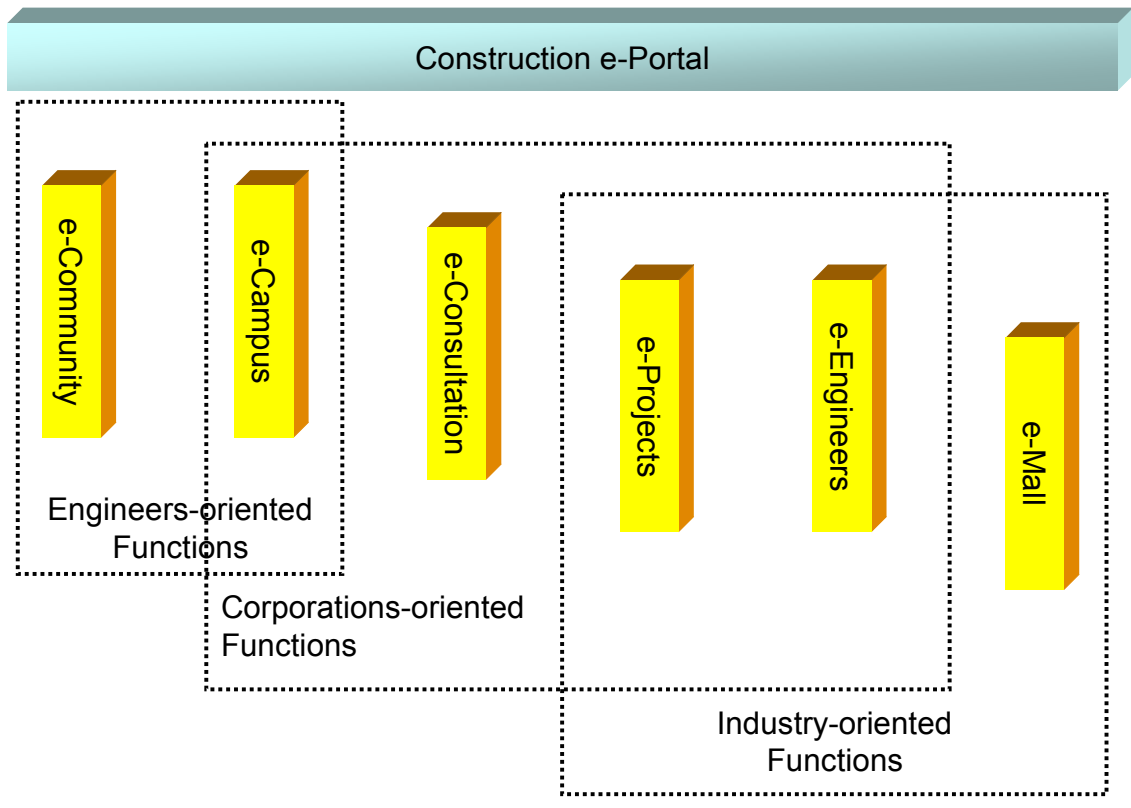

Figure 3. Dependency of e-Portal Modules and Users

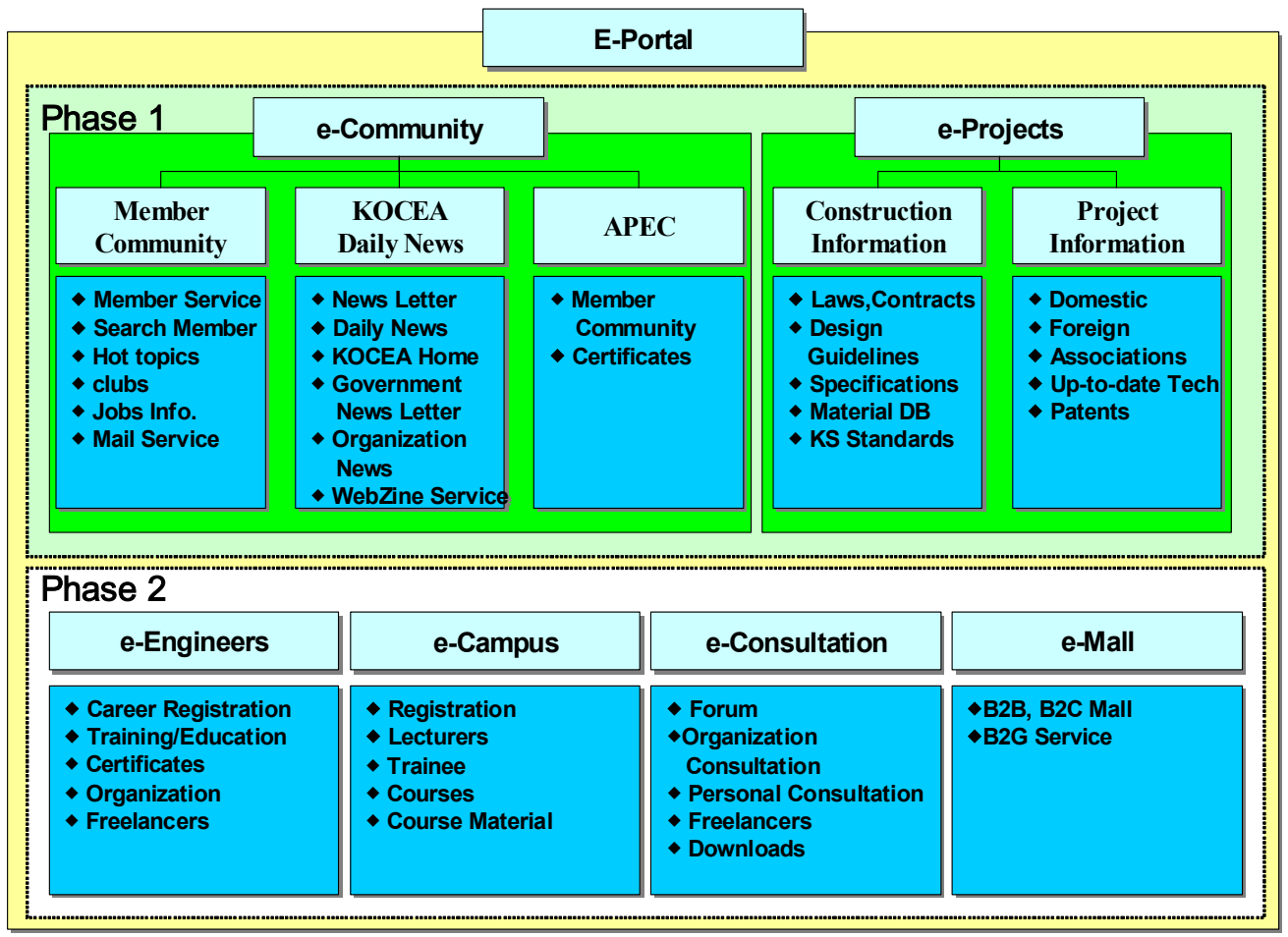



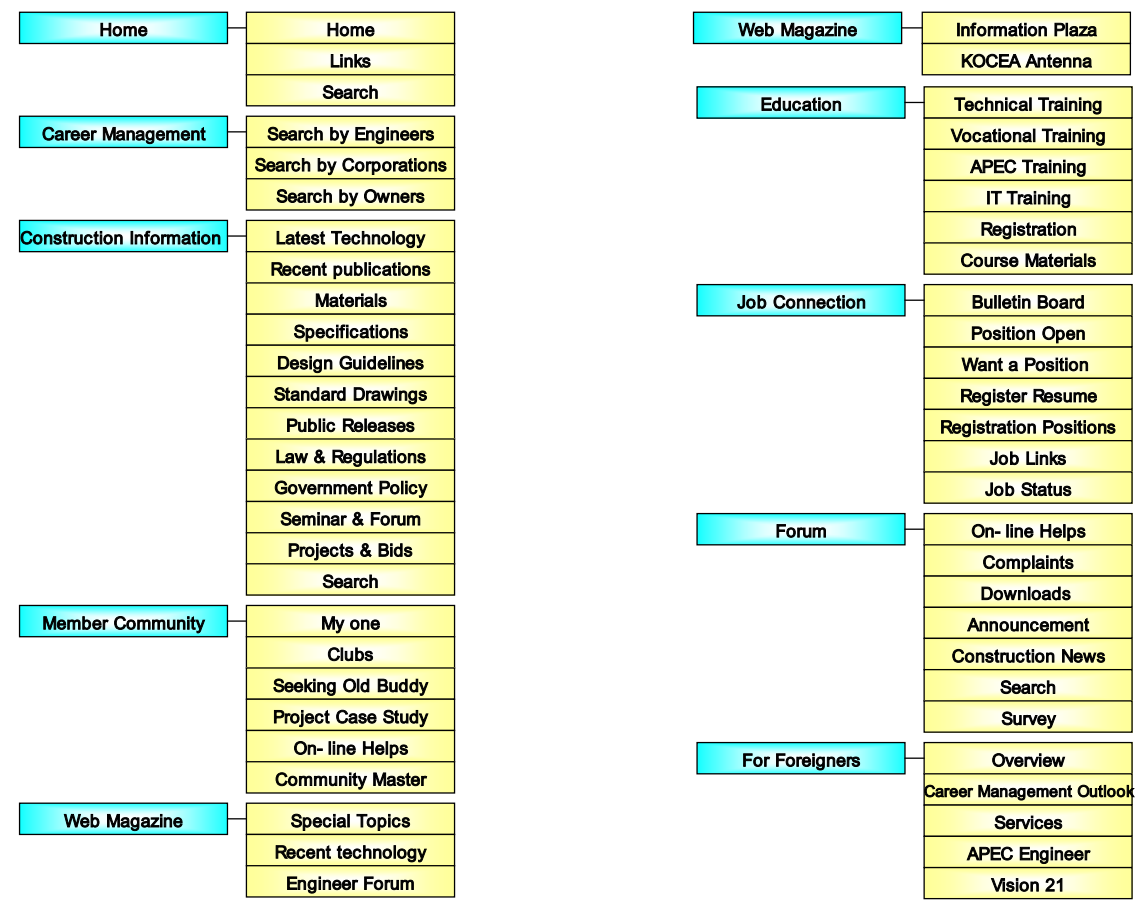

Figure 5. Sub-functions of e-Portal

The 4-Tier platform uses the "Model, View and Controller" (MVC) to present information as shown in Figure 7. The MVC architecture has been used as development architecture because it simulates input-process-output model. The Model encapsulates a real world problem and formulates into a comprehensive and functionally compatible process form. The Controller interacts with the Model and the View. The Controller is a logical process of real world business processes. As described in Figure 8, templates (user interface) and their elements (utility functions) are designed, defining types of content, parsers to handle business processes, and views in order to combine templates and their content.
Using templates, pre-defined HTML pages, information can be deployed to homepages. Thus, the user interface can be modified by simply changing templates. With XML data format, information can also be deployed to different types of user interfaces such as WAP (Wireless Application Protocol), PDA (Personal Digital Assistant), and other XML. Figure 9 shows a homepage of an operating e-Portal. According to the verified membership level of a user, different levels of construction information is available. Most frequently asked information such as job openings, new technologies and new construction methods, construction project bids, APEC information, the latest laws and regulations are posted. 


\begin{tabular}{|c|c|c|}
\hline Technology & Layer & Function \\
\hline $\begin{array}{r}\text { XML via XSL to } \\
\text { HTML, XML }\end{array}$ & Presentation & $\begin{array}{l}\text { Layout of information to end } \\
\text { user (user interface) using } \\
\text { various platforms }\end{array}$ \\
\hline $\begin{array}{r}\text { Servlets and } \\
\text { EJBs }\end{array}$ & Application & $\begin{array}{l}\text { Applications and toolsets of } \\
\text { business processes, event } \\
\text { processes }\end{array}$ \\
\hline EJBs & API & $\begin{array}{l}\text { Internal functions/modules } \\
\text { to support application } \\
\text { development }\end{array}$ \\
\hline $\begin{array}{r}\text { Stored } \\
\text { procedures }\end{array}$ & Database & $\begin{array}{l}\text { adapters for internal and } \\
\text { external databases }\end{array}$ \\
\hline
\end{tabular}

Figure 6. Framework of Internal Architecture (Modified after Dmind (2001)).

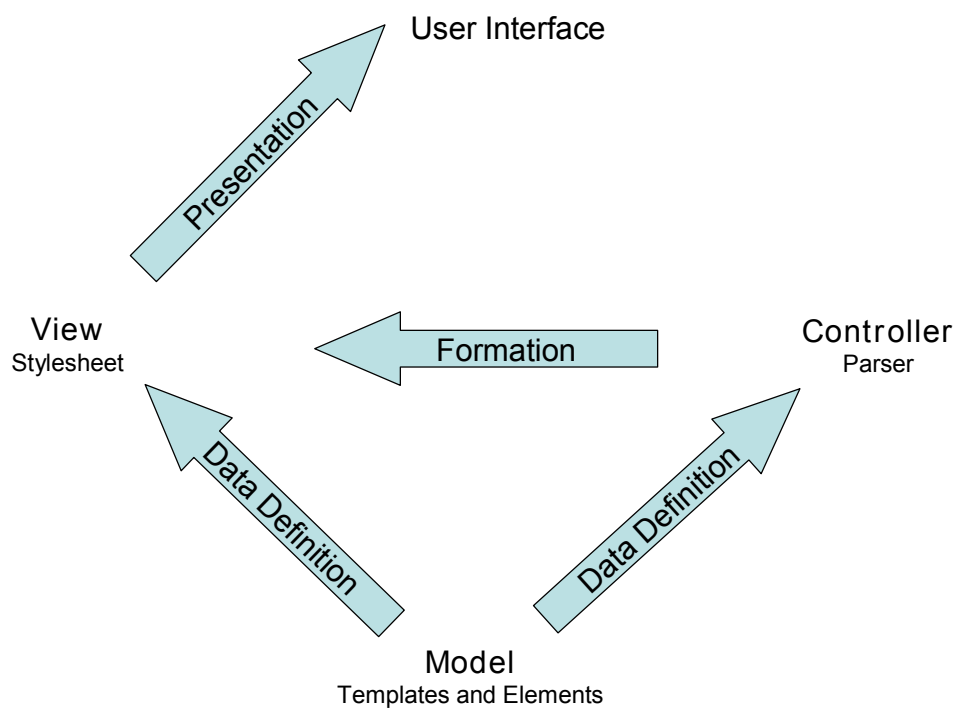

Figure 7. MVC Architecture (Dmind 2001). 


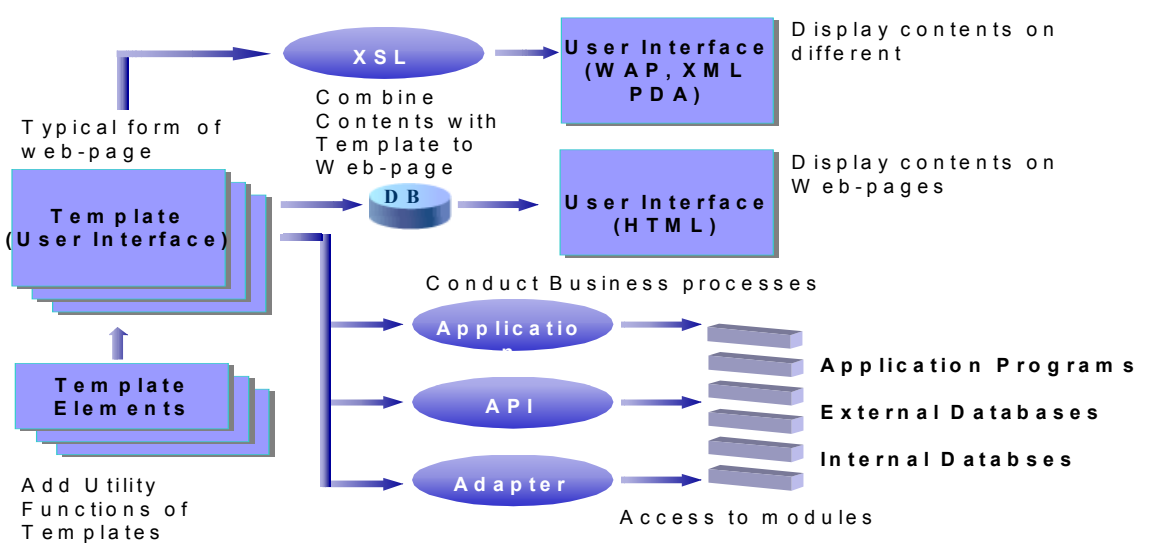

Figure 8. Implementation Model Implementing MVC.

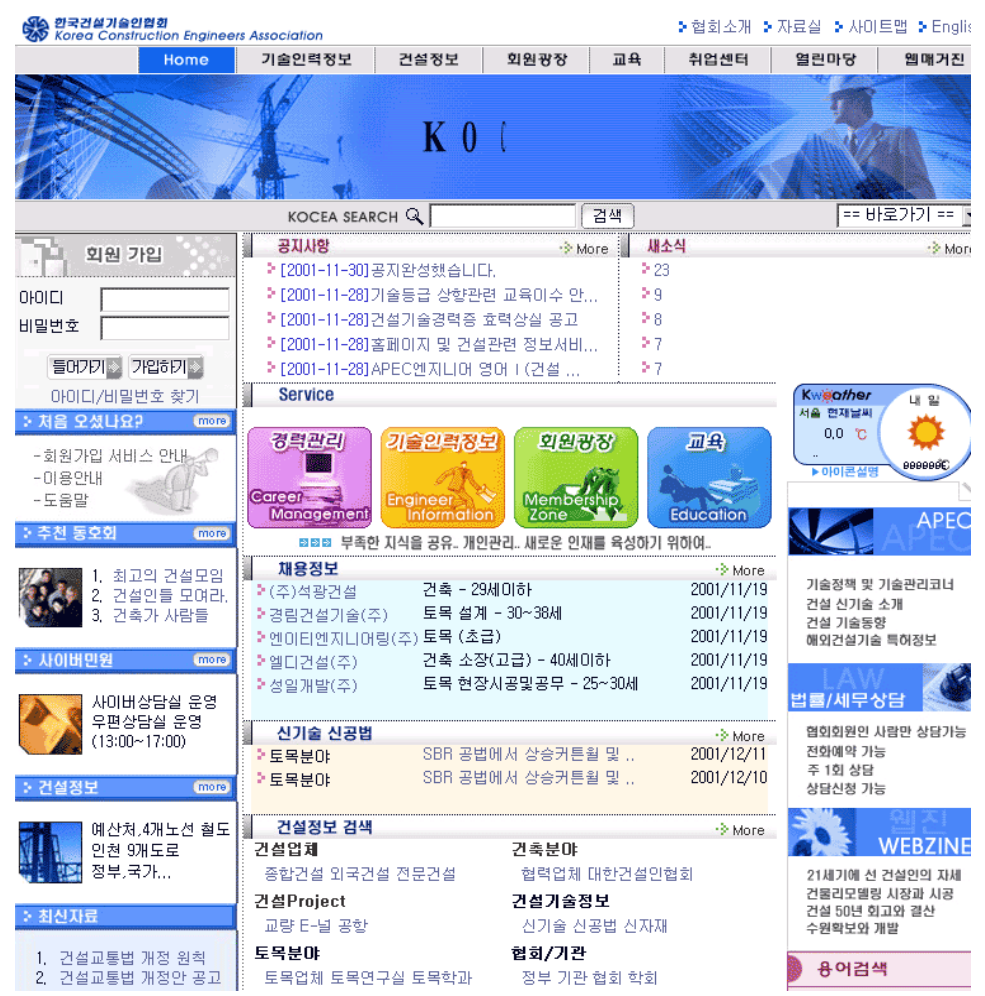

Figure 9. A Homepage of e-Portal

\subsection{Databases}

Figure 10 shows the interconnection of databases. Integration of e-Portal and Career Management System allows a more convenient access to both systems, a feature which draws more users. EPortal must allow users to access various databases to handle their transaction. E-Portal is closely connected with the existing Career Management System in order to support career management services for project owners, contractors and engineers under the supervision of KOCEA. Thus, inconsistency of career records can be avoided. 


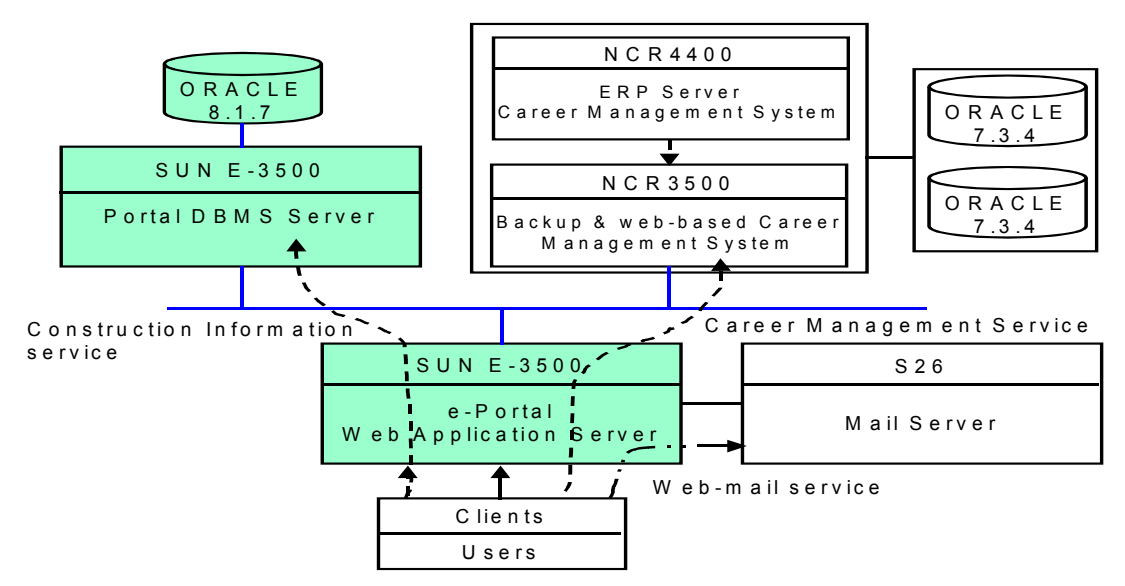

Figure 10. Interconnection of Databases.

In order to provide customized information for ePortal, construction information is classified as shown in Table 3 and organized according to the survey described in Figure 2. The information is broken down into four categories and linked to six modules. KOCEA provides industry information. Corporate information offered by manufacturers is accessible if KOCEA confirms the validity of the given information. Project information is available but limited to public project documents. KOCEA provides on-line training and educational materials based on the professional development requirements.

Table 3. Contents of Construction Information covered by e-Portal

\begin{tabular}{|c|l|c|}
\hline Type of Information & \multicolumn{1}{|c|}{ Major Classification Index } & Associated Modules \\
\hline \multirow{5}{*}{ Industry Information } & $\begin{array}{l}\text { Law and regulations. } \\
\text { Standard specifications and secondary } \\
\text { specification. } \\
\text { Technical manuals. } \\
\text { Design guidelines. }\end{array}$ & e-Community \\
\hline \multirow{3}{*}{ Corporate Information } & $\begin{array}{l}\text { Construction materials. } \\
\text { Manufacturers. } \\
\text { Vendors and suppliers. } \\
\text { National standards. }\end{array}$ & $\begin{array}{l}\text { e-Community } \\
\text { e-Mall }\end{array}$ \\
\hline \multirow{2}{*}{ Individual Information } & $\begin{array}{l}\text { Project documents. } \\
\text { Programs in engineering and construction } \\
\text { operations. }\end{array}$ & $\begin{array}{l}\text { e-Projects } \\
\text { e-Engineers }\end{array}$ \\
\hline & $\begin{array}{l}\text { Certificates and licenses. } \\
\text { maining and education including education }\end{array}$ & $\begin{array}{l}\text { e-Consultation } \\
\text { e-Engineers } \\
\text { e-Campus }\end{array}$ \\
\hline
\end{tabular}

Registering through the e-Portal allows users to have a virtual space at the e-Portal. A users is allowed to create his/her own community and a repository to keep one's own files and programs. Thus, repository can be opened to the community members. In addition, KOCEA offers professional consultation services through Frequently Asked Questions (FAQ) functions. Qualified professionals from the specialty fields provide online answers to the requests from users. KOCEA has also provided electronic training and education materials of over eighty courses to those in need of continuing professional development credits for the renewal of engineering certificates and licenses.

Figure 11 shows transactions between the users and the e-Portal. Verification of the membership and validation of career information are easily completed when the Career Management System (CMS) is linked to the portal. By collecting patterns of information requested, construction 
information can be re-organized by the recent preference of users.

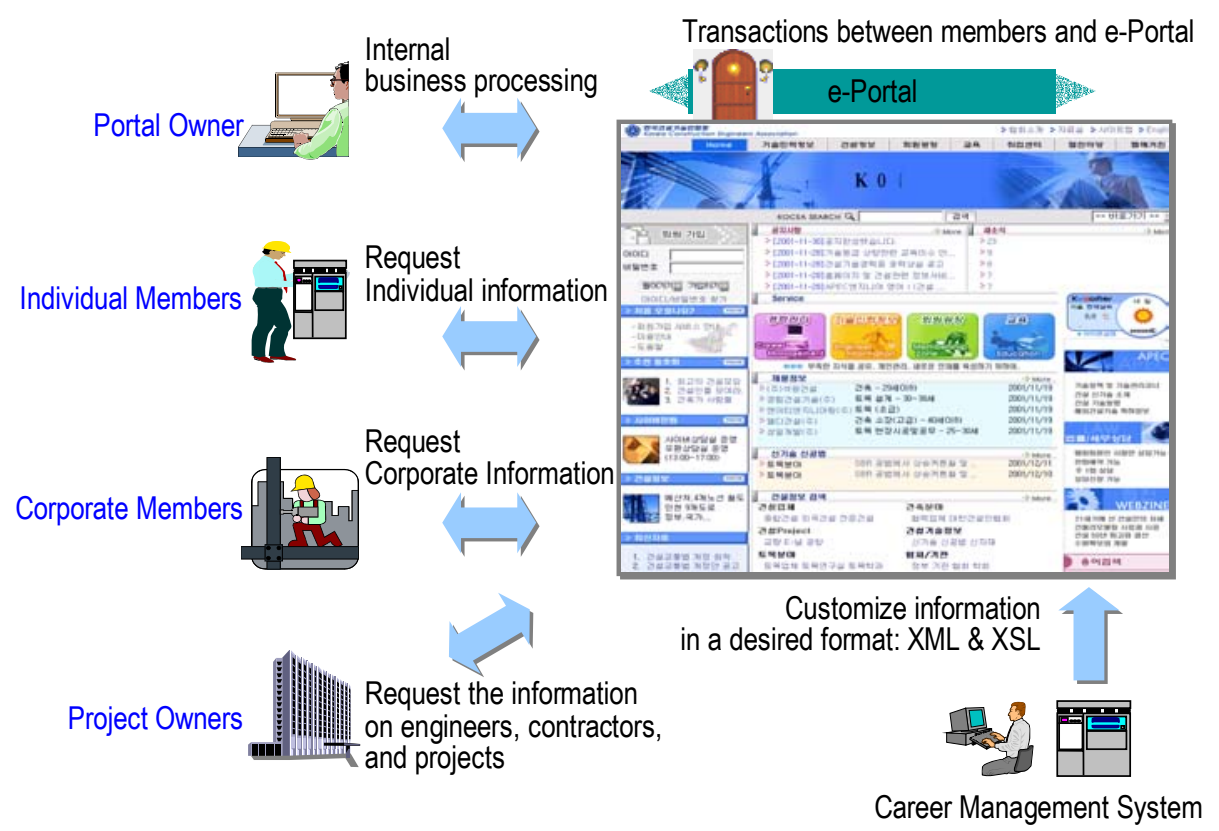

Figure 11. Interaction between users and e-Portal

The number of visits to the e-Portal is increasing because the portal has been designed according to the suggestions of engineers. Each curve in Figure 12 , from top to bottom, represents the numbers of visits to the KOCEA Home, number of IDs issued, Career Management, Open Community, Job Connection, New Construction Project Information, Member's Community, KOCEA Community, Education and Training, Web Magazine, and Foreigners.

\section{CONCLUSIONS AND FUTURE DEVELOPMENTS}

A functional framework and a system architecture are identified for a construction e-Portal considering 4-Tier architecture. The architecture is beneficial to enhancing the integrity of the portal due to the variety of information and applications available. In addition, following observations are recommended. Classification of construction information must be defined before the development of e-Portal. This 4-Tier platform is an effective tool in order to allow extension and integration of e-Portal. Using the platform requires less training and education to system operators. To enhance serviceability of e-Portal, its extension is necessary because the changing characteristics of the construction industry. Depending on project delivery methods and contract delivery methods and the definition of contents, additional subfunctions may be necessary.

\section{REFERENCES}

Abduh, M., Skibniewski, M. (2002a): “Optimal Configuration of Electronic Networking Technologies for Supporting DesignBuild Projects," Journal of Civil Engineering and Management, Vol. VIII, No. 4, Vilnius Gediminas University and Lithuanian Academy of Sciences, ISSN 1392-3730, pp. 240-254

Abduh, M., Skibniewski, M. (2002b): "Utility of Internet-Based Applications in Construction," International Journal of Construction Management, Chinese Research Institute of Construction Management, Hong Kong, Vol. 2, No. 1, ISSN 1562-3599, pp. 65-81

Abduh, M., Skibniewski, M. (2003): "Utility Assessment of Electronic Networking Technologies for Design-Build Projects," Automation in Construction, Elsevier Science Publishers, Vol. 12, No. 2, March, pp. 167-184 
Castro-Lacouture, D. and Skibniewski, M. (2003):

"Applicability of E-Work Models for

Automation of Construction Materials

Management Systems," accepted by

Production Planning and Control,

Taylor \& Francis Publishers, ISSN

0953-7287

Castro-Lacouture, D., Nitithamyong, P., Ryoo, BY., Skibniewski, M. (2003): "Design of B2B e-Work Solution for the Supply Chain of Construction Reinforcement Steel," under review by IT-CON Electronic Journal of Information Technology in Construction, ISSN 1400-6529, Special Issue on E-Business and E-Work

Dmind Corporation (2001) nGia (Next Generation Internet Application) Architecture White Paper, New York, USA.

Flanaga, D., Farley, J., Crawfor, W., and Magnusson, K. (1999) Java TM Enterprise in a Nutshell, $1^{\text {st }}$ Edition, O'Reilly \& Associates, USA.

KOAK(2001) Domestic Construction Trends in 2001.

Li, H., Cao, J., Castro-Lacouture, D., Skibniewski, M. (2003): "A Framework for Developing a Unified B2B E-Trading Construction Marketplace," Automation in Construction, Elsevier Science Publishers, Vol. 12, No. 2, March, pp. 201-212

MOCT(2001). Guideline of Releasing information on Public Construction Projects. Ministry of Construction and Transportation (2001.02.08).

Ryoo, B. Y. (2001) Enhancement of e-Business in Construction. Symposium on IT in Construction 2001, November 11, 2001, Seoul Korea.

Ryoo, B. Y. (2002) Development of Internet Portal Site for Construction Engineers, Journal of project management \& Technology, v.6, pp. 11-18. 